\title{
Experimental comparison of efficiency and emission levels of four-cylinder lean-burn passenger car-sized CNG engines with different ignition concepts
}

Today's passenger car CNG engines are based on petrol engines which typically have restrictions preventing the exploitation of the full potential of methane based fuels, especially if they have to be operated also on petrol as a second fuel. Additionally, the use of threeway-catalysis limits the engine operation to $\lambda=1$. Here, we present the efficiency potential and the raw emission characteristics for a dedicated four cylinder passenger car CNG engine without sticking to the usual combustion peak pressure and $\lambda$ limitations. Lean combustion reduces the knocking tendency but, because of the higher pressure levels, increases the ignition energy demand. Therefore, different ignition systems (spark plug, prechamber, Diesel pilot) have been used.

Keywords: dual-fuel, diesel pilot, spark ignition, prechamber

\section{Introduction}

Natural gas offers distinct $\mathrm{CO}_{2}$ advantages over classical liquid fuels and it is therefore of interest in the mobility sector $[12,14]$. Additionally, renewable methane is chemically identical with the natural gas' main component methane and can be therefore blended in any ratio without need to change engine hardware or calibration. Hydrogen can also be added to Methane which leads to additional advantages, especially if engine control parameters are adapted [16]. All this gives compressed natural gas (CNG) an ecologic and economic long-term perspective in the mobility sector. Consequently, natural gas is one of the attractive fuel options for the automotive industry which is facing worldwide continuously tightening $\mathrm{CO}_{2}$ emission regulations [17].

Today's mass-produced natural gas engines for passenger cars are typically based on petrol engines, mostly with some adaptations such as increased compression ratio, increased boost pressure, adapted valves and valve seats, or high-temperature-capable turbine materials. Such adaptations do not fully take the advantageous properties of natural gas into account as for example the peak combustion pressure limitation of typically around 100 bar remains from the basic petrol engine. Passenger car natural gas engines are nowadays operated stoichiometrically which leads, in combination with three-way-catalysis, to very low emissions not only in legislative cycled but also in realworld operation [1]. Also, natural gas engines have the potential for practically zero emissions [2]. However, it is well-known that stoichiometric operation leads to reduced efficiencies compared to lean operation, especially due to higher pumping losses and heat transfer [5].

In the project described here, limitation regarding combustion peak pressure levels and stoichiometric operation are omitted to find the potentials and constraints for natural gas combustion in passenger-car-sized engines. A Diesel engine is used as an experimental basis as modern Diesel engines can cope with considerably higher peak pressures than gasoline engines. High combustion pressures, especially at lean conditions, need high ignition energies and a special focus is therefore put on the ignition systems. Three distinctly different ignition systems are used: An inductive ignition system using a well-insulated spark plug (engine 1), an inductive ignition system in prechambers of different geometries which could be used with or without prechamber gas injection (engine 2), and a Diesel pilot injection system (engine 3).

\section{Engines}

The engines for the spark ignited versions had gone through the following modifications:

- inserts for spark plugs (engine 1) or prechambers (engine 2) instead of the Diesel injectors,

- modified valve seats (engines 1 and 2),

- reduced swirl level (engines 1 and 2),

- modified pistons / modified piston rings (engines 1 and 2),

- wastegate instead of VTG turbocharger (engines 1 and 2).

The Diesel pilot engine is only slightly modified by implementing a PFI CNG supply system; all other details are identical from the serial production Diesel engine. The engines are operated with rapid prototyping ECUs and in all engines, closed-loop center of combustion (COC) control is implemented. The main characteristics of the engines discussed here are listed in Table 1 and additional information is given in the following subsections.

Table 1. Main characteristics of the used engines

\begin{tabular}{|l|c|c|c|}
\hline & $\begin{array}{c}\text { Engine 1 } \\
\text { Spark Plug } \\
\text { Engine }\end{array}$ & $\begin{array}{c}\text { Engine 2 } \\
\text { Prechamber } \\
\text { Engine }\end{array}$ & $\begin{array}{c}\text { Engine 3 } \\
\text { Diesel Pilot } \\
\text { Engine }\end{array}$ \\
\hline Base engine & $\begin{array}{c}\text { Volkswagen } \\
\text { EA 288 }\end{array}$ & $\begin{array}{c}\text { Volkswagen } \\
\text { EA 288 }\end{array}$ & $\begin{array}{c}\text { Volkswagen } \\
\text { EA189 }\end{array}$ \\
\hline $\begin{array}{l}\text { \# of cylinders / } \\
\text { valves per cylinder }\end{array}$ & $4 / 4$ & $4 / 4$ & $4 / 4$ \\
\hline $\begin{array}{l}\text { Displacement } \\
{\left[\mathrm{cm}^{3} \text { ] }\right.}\end{array}$ & 1968 & 1968 & 1968 \\
\hline Bore/stroke [mm] & $81 / 95.5$ & $81 / 95.5$ & $81 / 95.5$ \\
\hline Compression ratio & 14.5 & 14.5 & 16.5 \\
\hline Ignition system & Inductive & Inductive & - \\
\hline Spark plugs & $\begin{array}{c}\text { NGK M12 } \\
\text { in open } \\
\text { chamber }\end{array}$ & $\begin{array}{c}\text { NGK M10 } \\
\text { in prechamber }\end{array}$ & - \\
\hline
\end{tabular}


Table 1 cont.

\begin{tabular}{|c|c|c|c|}
\hline $\begin{array}{l}\text { Diesel injection } \\
\text { system }\end{array}$ & - & - & $\begin{array}{l}\text { Common } \\
\text { Rail with } \\
\text { Piezo } \\
\text { Injectors } \\
\end{array}$ \\
\hline $\begin{array}{l}\text { Gas port fuel } \\
\text { injectors }\end{array}$ & Bosch NGI2 & Bosch NGI2 & Bosch NGI2 \\
\hline $\begin{array}{l}\text { Prechamber injec- } \\
\text { tors }\end{array}$ & - & Bosch NGI2 & - \\
\hline Turbocharger & Wastegate & Wastegate & VTG \\
\hline EGR & Not installed & Not installed & $\begin{array}{c}\text { Present, not } \\
\text { used }\end{array}$ \\
\hline ECU & $\begin{array}{l}\text { Rapid proto- } \\
\text { typing unit } \\
\text { (dSPACE) }\end{array}$ & $\begin{array}{l}\text { Rapid proto- } \\
\text { typing unit } \\
\text { (dSPACE) }\end{array}$ & $\begin{array}{l}\text { Rapid proto- } \\
\text { typing unit } \\
\text { (dSPACE) }\end{array}$ \\
\hline $\begin{array}{l}\text { Cylinder pressure } \\
\text { indication }\end{array}$ & $\begin{array}{c}\text { All } 4 \text { cylin- } \\
\text { ders using } \\
\text { Kistler } \\
\text { sensors }\end{array}$ & $\begin{array}{l}\text { All } 4 \text { cylinders } \\
\text { using Kistler } \\
\text { sensors }\end{array}$ & $\begin{array}{c}\text { All } 4 \text { cylin- } \\
\text { ders using } \\
\text { Kistler } \\
\text { sensors }\end{array}$ \\
\hline $\begin{array}{l}\text { Prechamber pres- } \\
\text { sure indication }\end{array}$ & - & $\begin{array}{l}\text { One precham- } \\
\text { ber using } \\
\text { Kistler sensor }\end{array}$ & - \\
\hline
\end{tabular}

\subsection{Spark plug engine (Engine 1)}

The cylinder head is redesigned to hold an insert with a spark plug instead of a Diesel injector. To achieve good combustion chamber geometry for premixed combustion, pistons with hemispherical bowls with a distinct squich-area are used. Figure 1 shows a cross-cut where the combustion chamber geometry can be seen. It shows also the flush-mounted water-cooled cylinder pressure sensor.

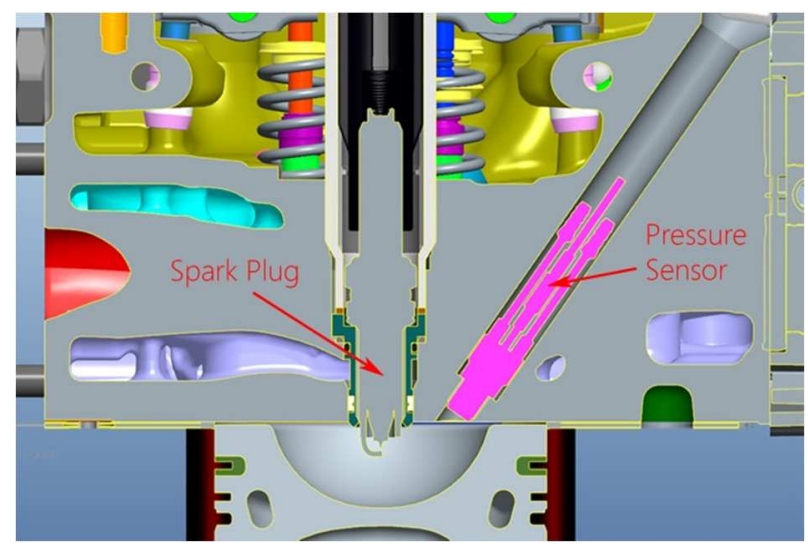

Fig. 1. CAD visualisation of the combustion chamber of the spark plug engine

Figure 2 depicts the intake manifold with the upstream throttle and gas mixer. A gas mixer enables a nearly perfect

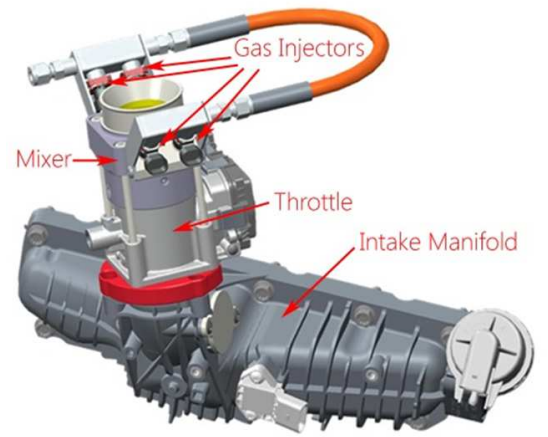

Fig. 2. CAD visualisation of gas mixer, throttle and intake manifold mixing of methane and air. The injection timing was synchronized to the crankshaft signal and the injectors were activated alternatively over $720^{\circ} \mathrm{CA}$ with the lowest possible rail pressure in order to enable injection durations as close as possible to $180^{\circ} \mathrm{CA}$. In comparison to a setup with the gas injectors mounted closer to the cylinder intake valves, the present setup is suited for transient operation only to a limited extent. However, this is not an issue since the focus of the work presented here lies on steady-state operation only.

\subsection{Prechamber engine (Engine 2)}

The prechamber engine is built on the same basis as the spark plug engine with the difference, that the cylinder head is equipped with specifically designed prechambers, see Fig. 3. Prechamber parts are shown in Fig. 4. Prechamber operation can be passive (i.e. without gas injection to the prechamber) or scavenged (i.e. with gas supply to the prechamber). A higly insulated M10 spark plug is used for ignition. A check valve at the prechamber entrance enables the use of a recessed dosing valve. Additionally, a small uncooled piezoelectric pressure sensor is implemented in the upper part of the prechamber. The prechamber insert are placed in cooling water channels and sealed with gasket rings.

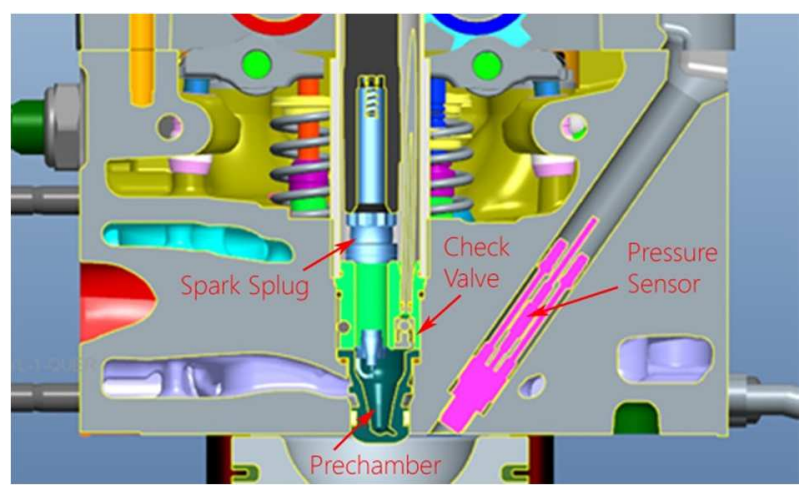

Fig. 3. CAD visualisation of the combustion chamber of the prechamber engine

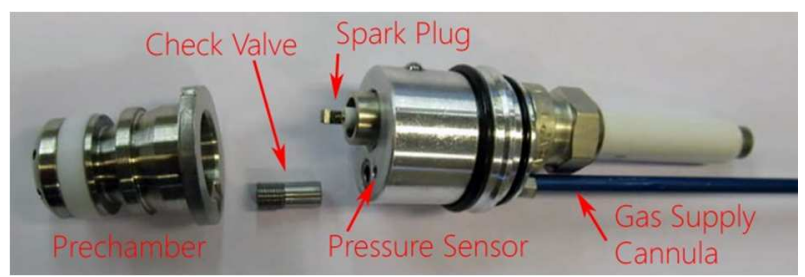

Fig. 4. Prechamber assembly, including the prechamber pressure sensor and the gas supply cannula

The air/fuel equivalence ratio $(\lambda)$ of the mixture inside the prechamber at time of ignition is crucial for the operation of the scavenged prechamber. The goal is to achieve a mixture inside the prechamber when ignition is applied which is close to stoichiometric condition. This is not a trivial task as during compression a lean mixture with a certain $\lambda$ is pushed back into the prechamber if the engine is run lean. Therefore, the resulting $\lambda$ at spark timing depends on the $\lambda$ in the main chamber, on the amount of gas injected to the prechamber and on the spark timing itself. A dedicat- 
ed prechamber controller adapts the injection and ignition timing based on the estimated prechamber $\lambda$ accordingly [6]. Finally, we optimized for best efficiency and lowest THC emissions which turned out to occur at early injection with the start of prechamber injection around $300{ }^{\circ} \mathrm{CA}$ before TDC.

Prechamber geometries are designed and optimized using CFD tools by Volkswagen Konzernforschung, Ricardo Software and ETH Zürich [3, 4, 10, 11, 15]. The performance of different prechamber designs was tested on a rapid compression and expansion machine at ETH Zürich and on a single cylinder engine at Poznan University of Technology with focus on prechamber performance $[9,13]$. A selection of prechambers was then implemented on the full engine described here where the behavior of the overall combustion system is addressed and engine efficiency and emission levels are assessed. In this article, we focus on two prechamber geometries which show a distinct different performance, both with identical volume but with a different channel configuration. Figure 5 shows a picture of the two prechambers and Table 2 lists the main characteristics.

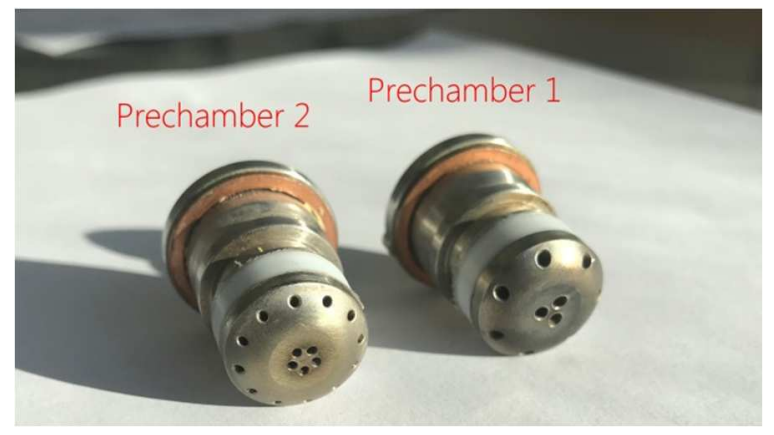

Fig. 5. Used prechambers (jet exit sides)

Table 2. Main characteristics of the prechambers compared in this study

\begin{tabular}{|l|c|c|}
\hline & Prechamber 1 & Prechamber 2 \\
\hline Prechamber volume & $1.826 \mathrm{~cm}^{3}$ & $1.826 \mathrm{~cm}^{3}$ \\
\hline $\begin{array}{l}\text { Number x diameter } \\
\text { of horizontal nozzles }\end{array}$ & $7 \times 1.5 \mathrm{~mm}$ & $12 \times 0.9 \mathrm{~mm}$ \\
\hline $\begin{array}{l}\text { Number x diameter } \\
\text { of vertical nozzles }\end{array}$ & $3 \times 1.4 \mathrm{~mm}$ & $5 \times 0.9 \mathrm{~mm}$ \\
\hline
\end{tabular}

\subsection{Diesel pilot engine (Engine 3)}

The Diesel pilot engine is only slightly modified for Diesel pilot operation: Four gas injectors are added to the swirl flap adapter just before the engine's intake channels (Fig. 6). The Diesel fuel is directly injected into the cylinders using the standard Diesel injection system. Once compression ignited, the Diesel provides ignition centres for the premixed natural gas. The amount of Diesel defines the level of energy that is available for the ignition of the gas/air mixture. The point in time at which the Diesel is injected, influences the type of combustion significantly. Very early injections allow for much better mixing of the Diesel with the gas/air mixture than it is the case with late injections. According to this, different injection strategies can result in combustions with the same combustion phasing but different $\mathrm{CO}_{2}$ emission, thermal efficiency and pollutant emissions. In this study, the Diesel injection parameters, i.e. the start and duration of injection, are chosen such that the desired combustion phasing is achieved using the least amount of Diesel possible [18]. In general, this "Minimal Diesel Control" minimizes the $\mathrm{CO}_{2}$ emissions of the engine as the substitution rate is maximized. In addition, when operated with a fixed total fuel/air mixture, fewer Diesel leads to less excess oxygen in the air/gas mixture. This favors flame propagation since laminar flame speed is increased. At high loads, the mechanical limitation on the maximum cylinder pressure prohibited the air/fuel ratios to exceed a $\lambda$ of about 1.4 .

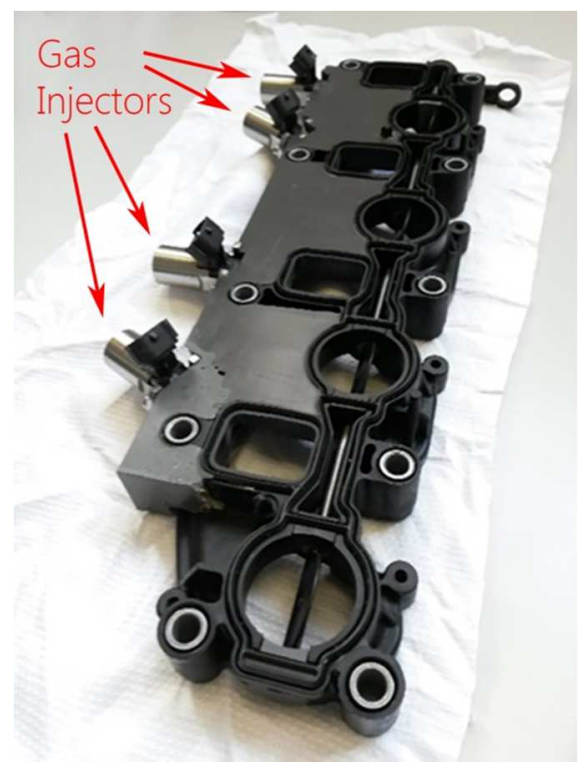

Fig. 6. Four PFI gas injectors mounted on the swirl flap adapter of the original Diesel engine

\section{Fuel}

For all experiments, natural gas from the local grid is compressed in bottles and fed to the engine's pressure regulators. The gas composition is analyzed from time to time using a process gas chromatograph. A stable gas composition was observed. Table 3 shows the main components. The resulting lower heating value is $48.6 \mathrm{MJ} / \mathrm{kg}$ (standard deviation $0.2 \mathrm{MJ} / \mathrm{kg}$ ) and the methane number is 87 (standard deviation 0.7 ).

Table 3: Composition of the used gas (values of 7 gas analyses)

\begin{tabular}{|l|c|c|c|c|c|}
\hline & Methane & Ethane & $\mathrm{CO}_{2}$ & Nitrogen & Propane \\
\hline Mean & 94.5 Mole\% & 3.5 Mole\% & 0.8 Mole\% & 0.5 Mole\% & 0.4 Mole\% \\
\hline $\begin{array}{l}\text { Standard } \\
\text { deviation }\end{array}$ & 0.4 Mole $\%$ & 0.2 Mole $\%$ & 0.1 Mole\% & 0.1 Mole\% & 0.1 Mole\% \\
\hline
\end{tabular}

\section{Results}

For the discussion of efficiency, emissions and temperature levels, we concentrate here on the following two operating points:

- Operating point 1 (low load): Engine speed $1400 \mathrm{~min}^{-1}$, brake torque $50 \mathrm{Nm}$ (bmep = 3.2 bar),

- Operating point 2 (higher load): Engine speed $2000 \mathrm{~min}^{-1}$, brake torque $220 \mathrm{Nm}$ (bmep = 14.0 bar).

Those two operating points cover all the dominant effects seen across the engine map. It has to be noted that the turbochargers are not able to cover all possible operating conditions from $\lambda=1$ until the lean limits at all engine speed/torque combinations. Especially at very lean condi- 
tions and in combination with high load operation and comparably low engine speed, boost pressure limitations occur which lead to a power loss since the desired $\lambda$ cannot be met. Such operating conditions are marked in the following Figures with a grey background.

\subsection{Brake engine efficiencies}

The base Diesel engine for the Diesel pilot experiments is not the same as the base engine for the spark ignited versions, also the turbocharges are different (VTG versus wastegate). Therefore, the direct comparison of absolute numbers can be misleading as the gas exchange losses and friction can be different. However, the main objective in engine design is generally to maximize the efficiency while meeting pollutant emission limits and keeping the engine in safe operation for all setups. In this section, we discuss the influence of different parameters on efficiency. Brake engine efficiencies depend on:

- The properties of the working fluid, which are influenced by the air-to-fuel ratio.

- The combustion duration, which is influenced by the air-to-fuel ratio, the in-cylinder charge motion and the ignition characteristics.

- The combustion phasing, whereas it was experimentally confirmed that the center of combustion at $8{ }^{\circ} \mathrm{CA}$ gives best efficiency for all cases so that this phasing was fixed for all experiments presented here (with exception of retarded combustion phasing for cases where knock occurred at $\mathrm{COC}=8^{\circ} \mathrm{CA}$ ).

- The completeness of combustion, which is influenced by the global air-to-fuel ratio, by the in-cylinder charge motion and by crevice volumes.

Figure 7 shows the measured brake engine efficiencies versus $\lambda$ for the lower load operating point. Best efficiencies occur in the $\lambda$ range of $1.5 \ldots 1.7$ for all concepts. The spark plug engine shows efficiencies very similar to the engine equipped with prechamber 2 , but prechamber 2 allowed keeping a high efficiency up to leaner mixtures.

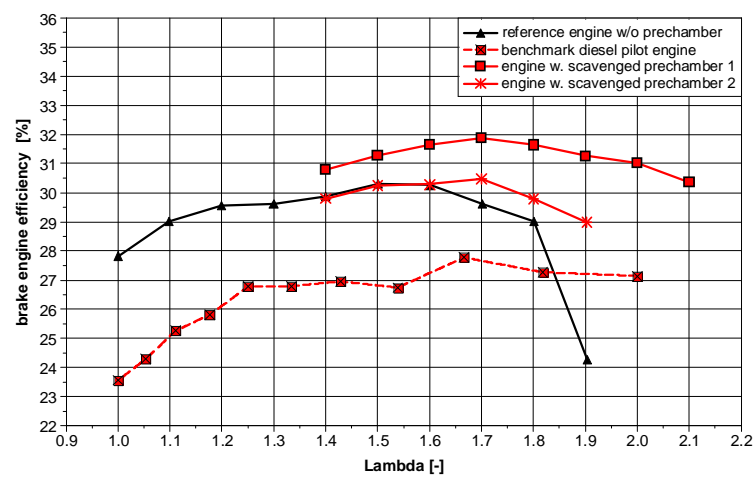

Fig. 7. Brake engine efficiencies for the operating point $1(1400 \mathrm{rpm} /$ $50 \mathrm{Nm} /$ bmep 3.2 bar)

The Diesel pilot engine shows a clear disadvantage in terms of efficiency which results from an impaired Diesel ignition. Since the fresh air is throttled under such load conditions, the pressure after compression diminishes and, in turn, the ignition delay is prolonged. Consequently, the Diesel mass for proper ignition has to be strongly increased, see section 3.3 and [7]. Prechamber 1 shows the best efficiency of all combustion concepts; it performs clearly better than prechamber 2, which points out the importance of the prechamber channel configuration.

Figure 8 shows the measured brake engine efficiencies versus $\lambda$ for the higher load operating point. Here, the spark plug option shows clearly the lowest efficiencies across the whole $\lambda$ range. The Diesel pilot setup peaks its efficiency at $\lambda=1.43$ where the allowed cylinder peak pressure is met. Prechamber 2 shows similar efficiency levels as the Diesel pilot setup, but was able to run leaner without hitting the peak pressure limit; this is mainly due to the lower compression ratio of 14.5 versus 16.5 of the Diesel pilot version. Also at this higher load point, prechamber 1 shows the best brake thermal efficiency level with nearly $44 \%$ at $\lambda$ levels around $1.6 \ldots 1.7$. The gray area in the plot shows the $\lambda$ region where the turbochrger was not able to deliver enough air, the resulting reducions in bmep are indicated.

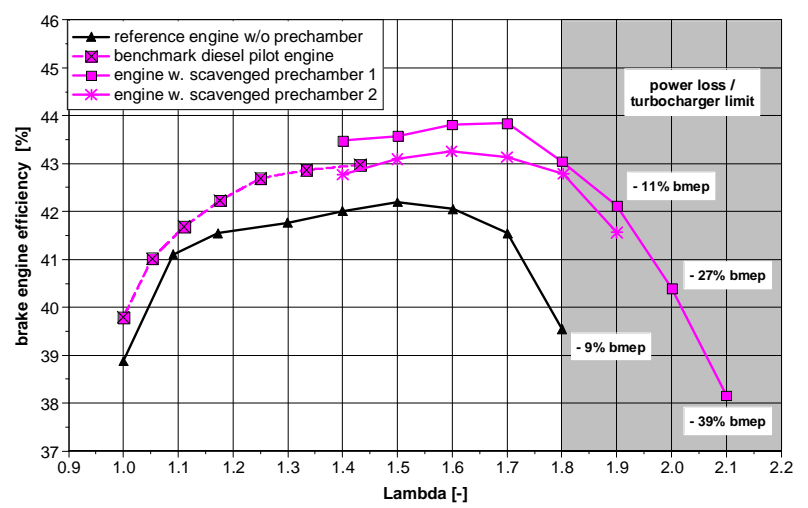

Fig. 8. Brake engine efficiencies for the operating point $2(2000 \mathrm{rpm} /$ $220 \mathrm{Nm} /$ bmep 14.0 bar)

\subsection{Peak cylinder pressure and center of combustion settings}

Figure 9 shows the peak cylinder pressures for the low load operating point. In all variants, the center of combustion (i.e. the crank angle where $50 \%$ of the fuel is burned) is set to $8{ }^{\circ} \mathrm{CA}$ after TDC. For the spark ignited versions, especially for the spark plug version, a clear increase in peak pressure with increasing charge dilution can be seen. In the region of best efficiency, the prechambers show higher peak pressures than the pure spark plug ignition. The

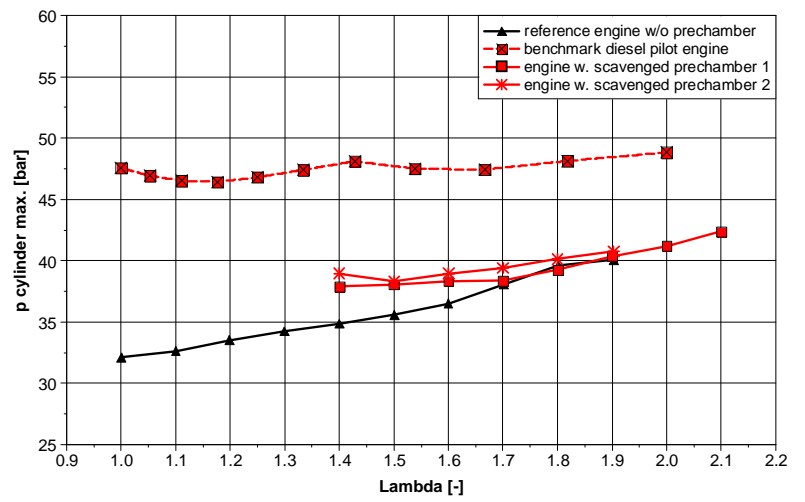

Fig. 9. Peak cylinder pressures for the operating point $1(1400 \mathrm{rpm} / 50 \mathrm{Nm} /$ bmep 3.2 bar) 
Diesel pilot engine shows the highest peak pressures levels in general, which is attributed to it's higher compression ratio. In this operating point with unfavorable conditions for the Diesel pilot and thus high Diesel pilot quantities, the peak pressure is fairly unaffected by increasing air dilution.

Figure 10 shows the cylinder peak pressure levels for the higher load point and Fig. 11 shows the corresponding settings of the center of combustion. For $\lambda$ values below about $1.4 \ldots 1.5$, the combustion phasing had to be delayed to prevent knock. At $\lambda=1$, the spark plug engine had the most delayed center of combustion setting which is attributed to the comparably slow combustion and therefore to an increased knock tendency. The Diesel pilot engine, even it has an considerably higher compression ratio than the spark ignited versions, could keep the center of combustion at a near-optimum level. This is most likely attributed to the fact that the Diesel pilot catches a large volume fraction of the cylinder filling which reduces the time for the end-gas to pass through pre-reactions. In terms of peak cylinder pressure levels, the Diesel pilot engines shows, due to its higher compression ratio, the highest levels. The spark plug engine shows the lowest levels. However, prechamber ignition increases the peak pressure levels which is attributed to considerably faster combustion compared to the spark plug version, see section 3.5.

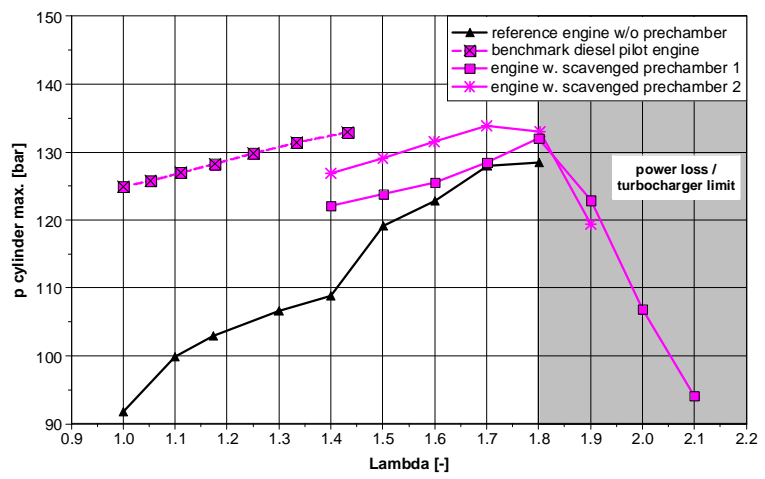

Fig. 10. Peak cylinder pressures for the operating point $2(2000 \mathrm{rpm} /$ $220 \mathrm{Nm} / \mathrm{bmep} 14.0 \mathrm{bar}$ )

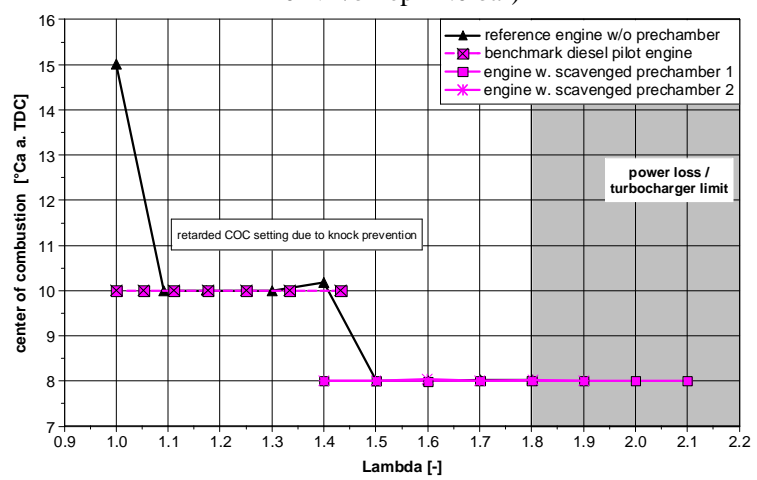

Fig. 11. Center of combustion settings for operating point $2(2000 \mathrm{rpm} /$ $220 \mathrm{Nm} /$ bmep 14.0 bar)

\subsection{Energy fraction for ignition}

In addition to the air/fuel mixture the engine aspirates, the Diesel pilot and the prechamber versions use additional fuel for the ignition process. For the Diesel pilot engine, the amount of pilot fuel is minimized to minimize soot formation and to use as little Diesel of this more carbon- intensive fuel as possible [18]. In case of the prechaber variants, the amount of gas supplied to the prechamber is set in such a way, that the efficiency is maximised [6]. The resulting energetic amounts of fuel provided to the prechambers and the Diesel pilot respectively are shown in Fig. 12 and Fig. 13 for the two discussed operating points. For the prechambers, the necessary amount of fuel provided to the prechamber increases with increasing charge dilution for both operating points whereas prechamber 2 needs more fuel than prechamber 1 , in spite of the same prechamber volume. This points out the strong coupling of the flow and composition structure in the prechamber with its performance. For the Diesel pilot engine, the energetic share for the Diesel pilot strongly increases at decreasing load, especially with decreasing air excess. This is because of the unfavourable conditions for compression ignition when pressure levels are decreased with intake flow throttling. At higher load conditions, the minimum amount of Diesel fuel is used which the injectors can provide. With the injectors used, this is the case with injection durations of around $120 \mu \mathrm{s}$.

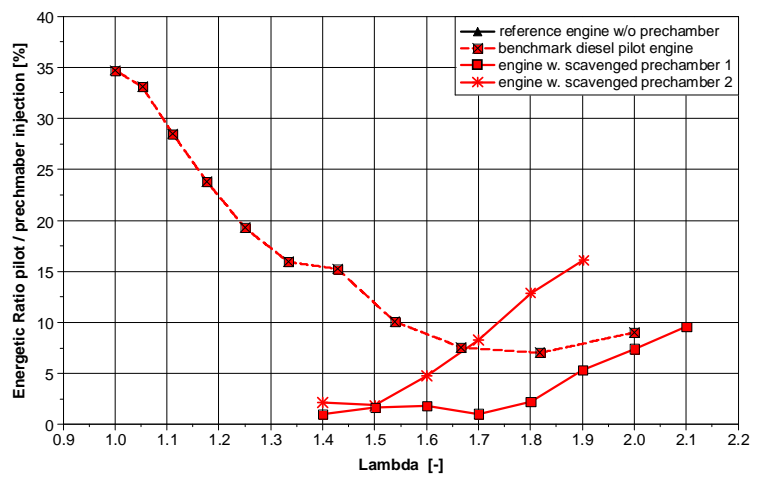

Fig. 12. Energy fraction for Diesel pilot or prechamber fueling for operating point 1 (1400 rpm/50 Nm/bmep 3.2 bar)

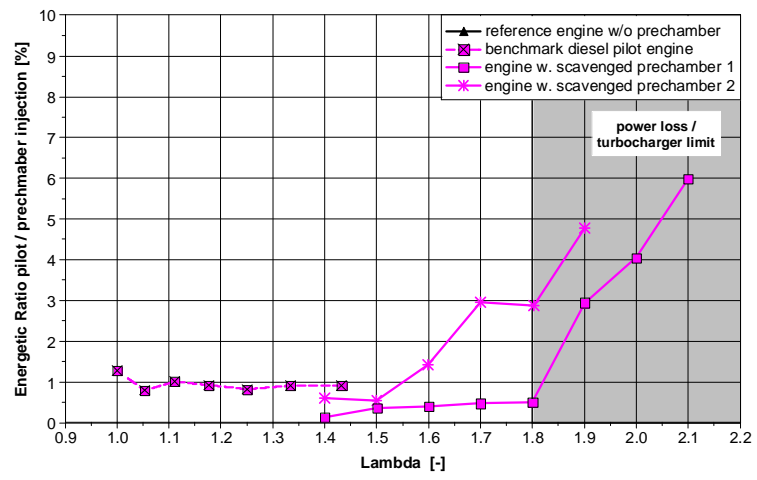

Fig. 13. Energy fraction for Diesel pilot or prechamber fueling for operating point $2(2000 \mathrm{rpm} / 220 \mathrm{Nm} / \mathrm{bmep} 14.0 \mathrm{bar})$

\subsection{Combustion stability}

To assess combustion stability, the coefficient of variation of the indicated mean effective pressure (CoV(IMEP), which is standard deviation divided by mean value) is usually taken as a measure. Here, we calculated the CoV(IMEP) based on 300 consecutively recorded in-cylinder pressure traces of cylinder \#1. CoV(IMEP) values below about $5 \%$ are typically regarded as desirable as these levels of cyclic variations guarantee a smooth engine operation. 
Figure 14 shows the cyclic variation levels for the lower load operating point. The spark plug and prechamber 2 overshoot the desired CoV(IMEP) levels above a $\lambda$ value of 1.8 and reach there their lean burn limits. Prechamber 2 does not show this behaviour at all; it enables stable combustion to well above $\lambda$ values of 2 . The same can be observed for Diesel pilot operation.

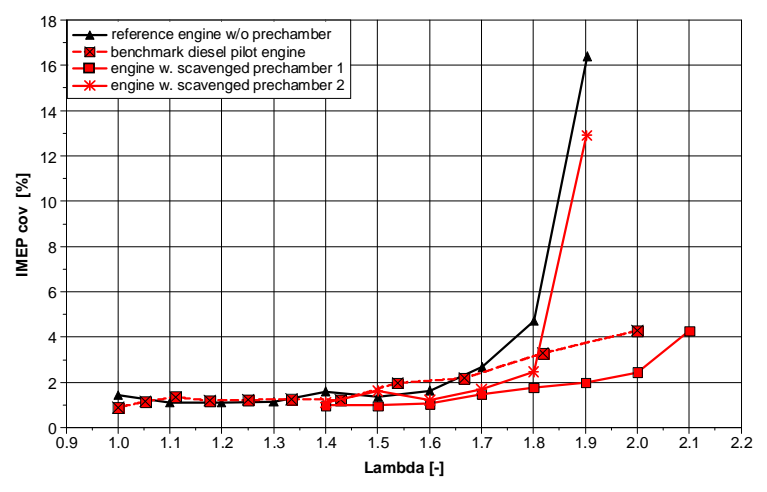

Fig. 14. Cyclic variations for the operating point $1(1400 \mathrm{rpm} / 50 \mathrm{Nm})$

Figure 15 shows the cyclic variation levels for the higher load operating point. Here, a similar behaviour can be observed for the spark ignited variants: the spark plug versions has its lean burn limit at a $\lambda$ value of 1.8 , the prechamber 2 at a slightly higher $\lambda$ value, prechamber 1 runs stable even at $\lambda$ values above 2 . The Diesel pilot engine shows a completely different behaviour than for the lower load operating point: $\mathrm{CoV}$ (IMEP) increases already at comparably low air dilution levels. The reason for this behaviour is most likely the cyclic variability of the Diesel pilot quantity. At high load, the Diesel quantity is very small and at the operating border of the Diesel injectors, see section 4.3.

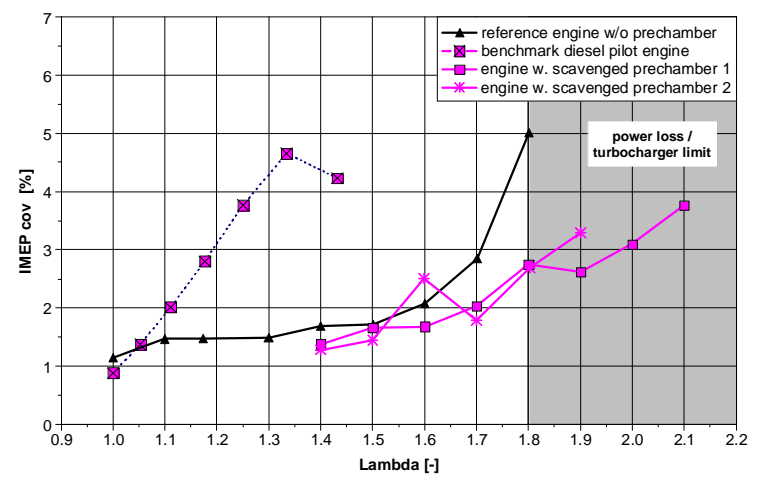

Fig. 15. Cyclic variations for the operating point $2(2000 \mathrm{rpm} / 220 \mathrm{Nm})$

\subsection{Combustion duration}

Ignition systems affect the subsequent combustion considerably. The ignition systems discussed in this paper are very different. A spark plug driven by a capacitive ignition system creates a thermal plasma which initializes flame propagation directly in the combustion chamber [8]. The flame development in case of a prechamber is protected from the combustion chamber and hot radicals are ejected [10], ignite the mixture and create turbulence. In case of a Diesel pilot ignition, a diffusion-controlled self-ignition of Diesel jets ignites the mixture. Because of these differ- ences in the underlying physico-chemical processes it is clear, that the combustion characteristics have to be very different.

Figure 16 shows the combustion duration, defined as the crank angle from $5 . . .90 \%$ mass fraction burned, for the low load point. The spark plug version shows the slowest combustion, whereas the prechambers lead to a much faster combustion. The Diesel pilot, which is energetically a large amount in this operating point (see section 3.3) leads to extremely fast combustion.

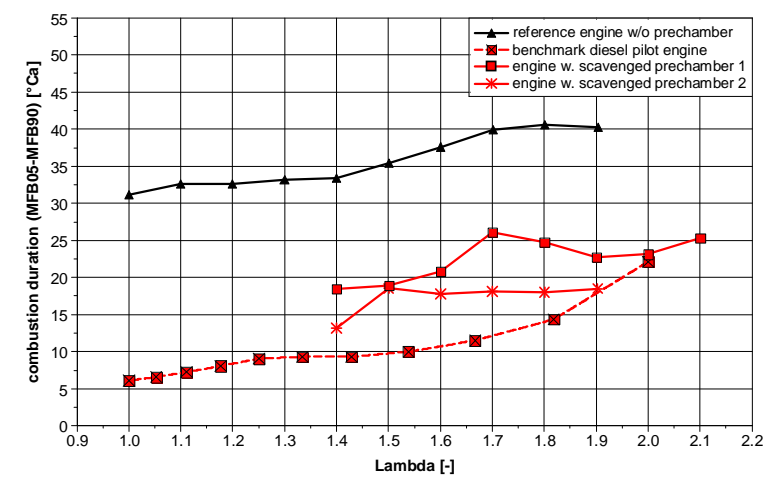

Fig. 16. Combustion durations for the operating point $1(1400 \mathrm{rpm} / 50 \mathrm{Nm})$

Figure 17 shows the combustion durations for the higher load point. In this point, the Diesel pilot engine shows similar combustion durations as the spark plug version. This is because at higher loads, the Diesel pilot quantities are much lower than at lower loads which transfers in a slower combustion. The prechambers show fast combustion, whereas prechamber 2 leads to even faster combustion than prechamber 1 . However, the faster combustion of prechamber 2 does not increase the thermal efficiency of the engine compared to prechamber 1 , neither in the high- nor in the low-load operating point. This is most likely attributed to increased wall heat losses due to very intense flame/wall interactions.

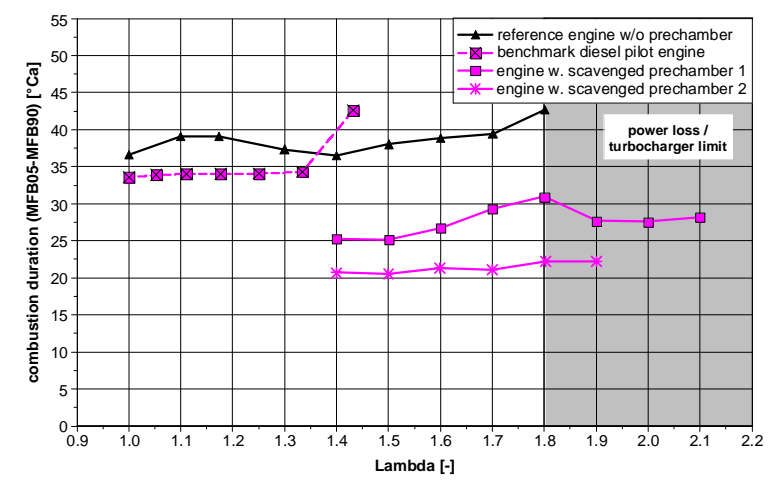

Fig. 17. Combustion durations for the operating point $2(2000 \mathrm{rpm} / 220 \mathrm{Nm})$

\section{6. $\mathrm{NO}_{\mathrm{x}}$ emissions}

The $\mathrm{NO}_{\mathrm{x}}$ emissions shown in Figure 18 and 19 indicate slight benefits for the prechamber engine concepts versus a simple spark plug for operation at a given $\lambda$. However, since the prechambers versions show best efficiencies at higher $\lambda$ values than the spark plug versions, the prechambers proved to be a very good approach to maximise effi- 
ciency and minimize $\mathrm{NO}_{\mathrm{x}}$ raw emissions. At $\lambda=1$, the Diesel pilot and the spark plug versions show very similar $\mathrm{NO}_{\mathrm{x}}$ levels for low- and high-load operation. At low load operation, the Diesel pilot version shows the highest $\mathrm{NO}_{\mathrm{x}}$ level at lean conditions. This is caused by the high amount of Diesel fuel used at these conditions.

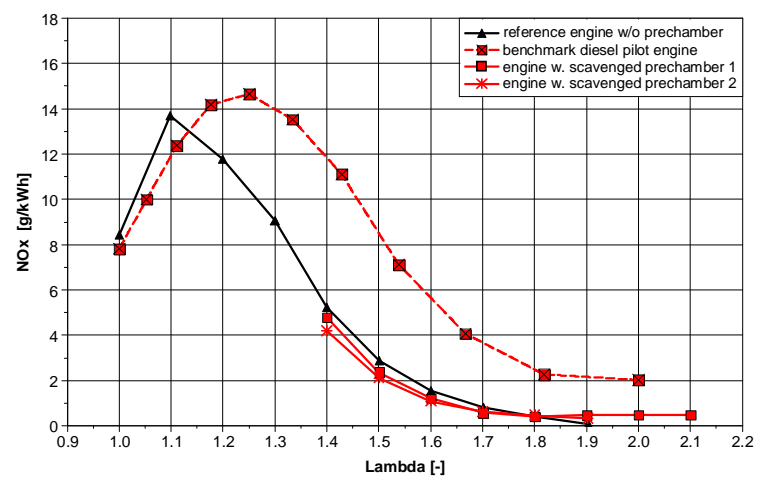

Fig. 18. Raw $\mathrm{NO}_{\mathrm{x}}$ emissions for the operating point $1(1400 \mathrm{rpm} / 50 \mathrm{Nm})$

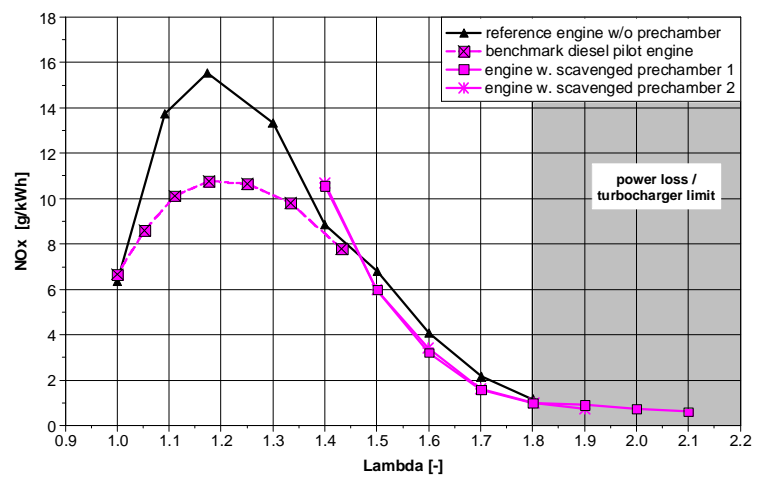

Fig. 19. Raw $\mathrm{NO}_{\mathrm{x}}$ emissions for the operating point $2(2000 \mathrm{rpm} / 220 \mathrm{Nm})$

\subsection{THC emissions}

The measured raw THC emissions, shown in Figs 20 and 21, indicate clear benefits for the prechambers. At low load, the Diesel pilot version with its high percentage of Diesel used shows the highest THC levels. The THC analyzer used for the Diesel pilot experiments was not able to distinguish between methane- and non-methane hydrocarbons so it is unknown, which portion of the THC emissions come from the Diesel pilot. However, as the Diesel share decreases with increasing air excess but the THC level increases monotonically it is very likely that the source of the THC emissions is not the Diesel pilot. As this engine has Diesel pistons without any optimization for low-HC crevices a large portion of the $\mathrm{HC}$ emissions may be caused by crevice volumes. For the prechamber engines, the methane- as well as the non-methane hydrocarbons were analyzed which revealed a stable methane share of 92 mole\% This corresponds well with the methane share in the fuel. The THC levels at lean conditions, especially at best efficiency setting at $\lambda$ above 1.5 , are generally high and ask for an efficient methane reduction technology under lean conditions, which is not yet available.

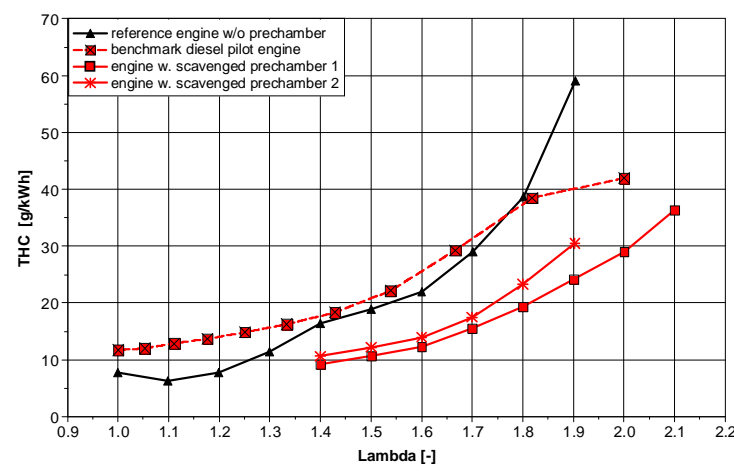

Fig. 20. Raw THC emissions for the operating point 1 (1400 rpm/50 Nm)

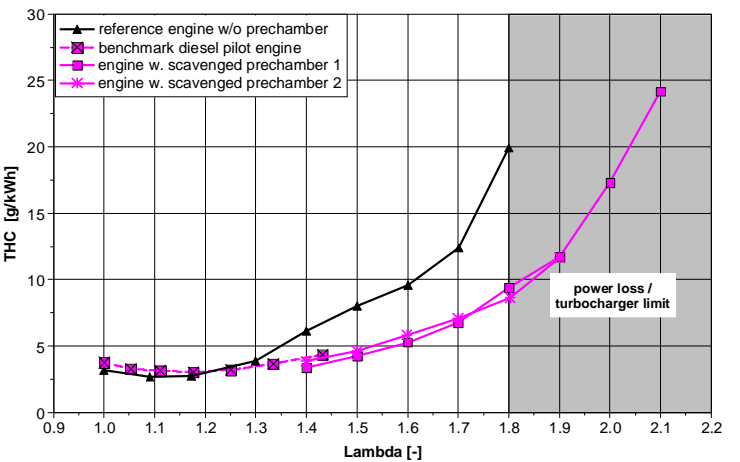

Fig. 21. Raw THC emissions for the operating point $2(2000 \mathrm{rpm} / 220 \mathrm{Nm}$ )

\subsection{Exhaust temperature levels}

Figure 22 and 23 show the temperature levels of the exhaust gases at turbine exit. This represents a location upstream of a potential exhaust aftertreatment system and indicates the thermal range of operation which could be expected for such a device. Due to the increasing air excess at lean burn operation, temperatures drop significantly and the temperature levels can become challenging for catalytic conversion, especially for methane oxidation.

Generally, the lowest exhaust gas temperature levels can be observed for the prechamber versions. This comes from on the one hand from the high efficiency level leading to less waste heat but, on the other hand, also to potentially increased heat losses to the cylinder walls.

The lower temperature level for lean combustion leads to challenges for exhaust gas aftertreatment but it reduces the thermal requirements for the turbocharger so that for example variable turbine geometries could be used.

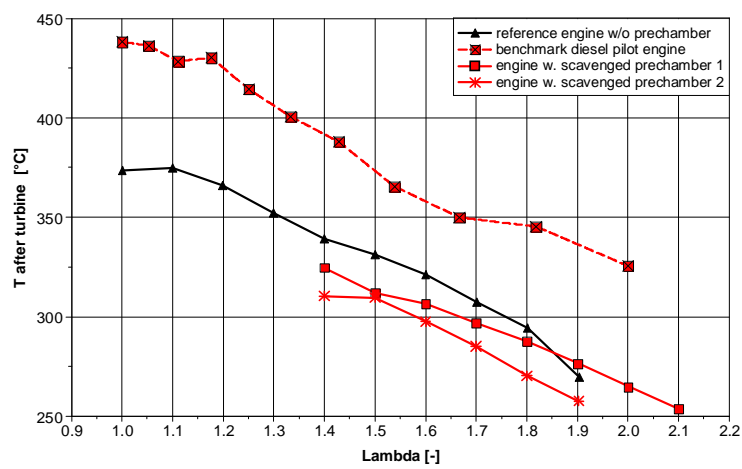

Fig. 22. Temperature after turbine for the operating point $1(1400 \mathrm{rpm} / 50 \mathrm{Nm})$ 


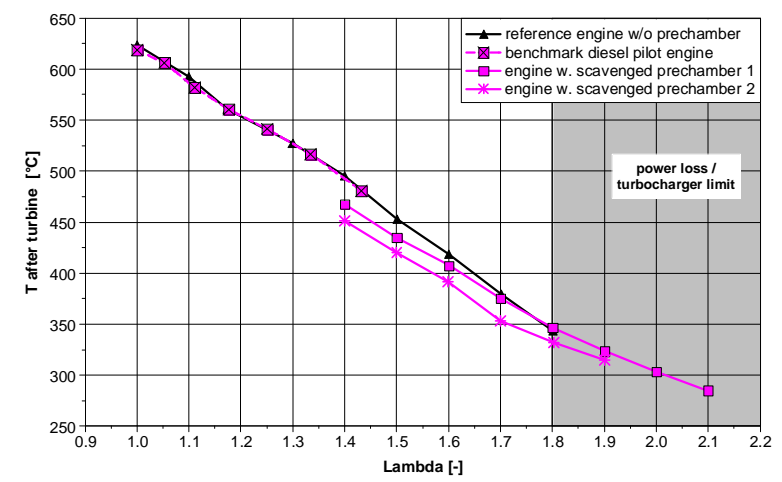

Fig. 23. Temperature after turbine for the operating point $2(2000 \mathrm{rpm} / 220 \mathrm{Nm})$

\subsection{Examples of cylinder pressure traces}

In order to directly compare cylinder pressure traces for the different configuration, an operating point is chosen which allows stable premixed combustion in all cases. At low load, the Diesel pilot engine needs a high Diesel share and at higher loads, the Diesel pilot engine is peak-pressure limited. Therefore, the comparison is done on a mediumload point at $15001 / \mathrm{min}$ and a brake torque of $100 \mathrm{Nm}$ (bmep $=6.4$ bar) and at $\lambda=1.7$, center of combustion was set to $8{ }^{\circ} \mathrm{CA}$ after TDC for all configurations. Figure 24 shows the corresponding $\mathrm{p}(\mathrm{V})$ diagrams in doublelogarithmic (left) and normal representation (right). The Diesel pilot version shows in this operating point the highest intake- and peak pressure levels. In this operating point, the Diesel pilot version shows also the lowest efficiency of all configurations (not shown here) which demands higher boost pressure. The very fast combustion of the prechamber versions, especially for prechamber 2 , can nicely be seen in the $\mathrm{p}(\mathrm{V})$ diagrams.
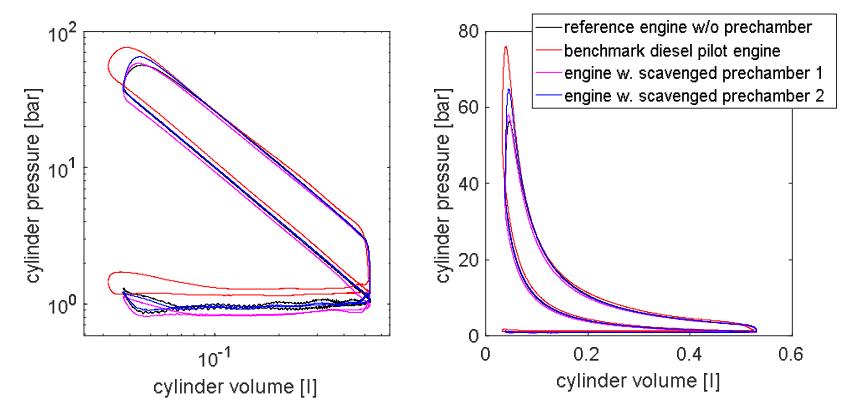

Fig. 24. Cylinder pressure versus cylinder volume for the operating point $(1500 \mathrm{rpm} / 100 \mathrm{Nm}), \lambda=1.7$ and $\mathrm{COC}=8{ }^{\circ} \mathrm{CA}$ after TDC

\subsection{Examples of net heat release rates}

Figure 25 shows the net heat release rates for the same medium load operating point as discussed for the cylinder pressure traces. Figure 25 also shows the ignition timings and the start of injection (SOI) timing for the Diesel pilot, respectively. The spark plug version needs the earliest ignition timing, the flame develops slowly and the peak heat release rate is comparably low. In contrast, the prechambers need much later ignition timing, the onset of combustion is very fast and the peak heat release rates are high. This is especially the case for prechamber 2 where the ignition timing is set to $7{ }^{\circ} \mathrm{CA}$ before TDC to achieve COC at 8 ${ }^{\circ} \mathrm{CA}$ after TDC, i.e. only $15{ }^{\circ} \mathrm{CA}$ later. Diesel-pilot ignition shows in this operating point a very similar heat release shape as the prechamber variants. The combustion noise characteristics for the prechamber-equipped and for the Diesel-pilot engines are therefore very Diesel-like; a hard combustion noise is clearly audible.

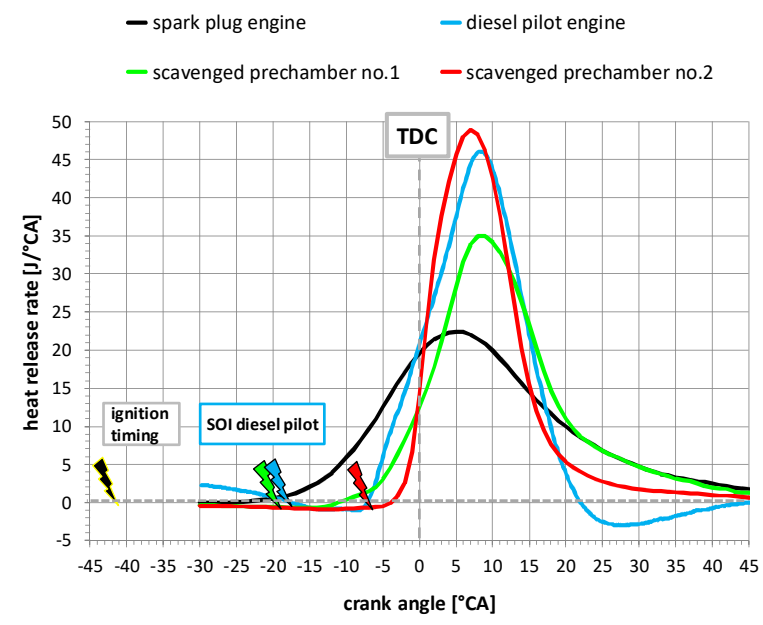

Fig. 25. Net heat release rates for operating point $1500 \mathrm{rpm} / 100 \mathrm{Nm}$ and $\lambda=1.7$

\section{Conclusions}

Among the engines considered here, the prechamberequipped engine showed the highest peak brake efficiency of nearly $44 \%$ at $\lambda$ around 1.7 and higher load levels. This is a Diesel-like efficiency level, even if the compression ratio is considerably lower than for typical Diesel engines. At such lean combustion, the prechamber enables moderate $\mathrm{NO}_{\mathrm{x}}$ levels in the order of $1 \mathrm{~g} / \mathrm{kWh}$ which would need a de$\mathrm{NO}_{\mathrm{x}}$ system such as SCR. The THC levels can be considerably lowered with a prechamber and lean combustion but levels in the order of $5 \ldots 10 \mathrm{~g} / \mathrm{kWh}$ need a very efficient methane oxidation technology, which is currently not available. The prechamber-equipped engines showed good performance and stable combustion across the whole engine map.

The Diesel pilot engine showed similar efficiency levels as the prechamber versions but at lower $\lambda$ values of around 1.4. Stable combustion could be achieved with only small Diesel pilot energies of about $1 \%$ at high load conditions. With decreasing load, especially at throttled operation, the Diesel pilot quantity has to be considerably increased to enable stable ignition and combustion. At extremely low loads, which are not discussed in this article, Diesel pilot operation is impossible and the engine has to be operated in pure Diesel mode. Therefore, lean Diesel pilot combustion proved to be a fuel-efficient concept for mainly high load operation.

The purely spark-plug equipped engine showed the poorest performance of all concepts. Combustion is comparably slow, the lean burn limit is comparably low and THC emissions are high. For efficient and low raw-emission lean-burn gas engines, prechamber or Diesel-pilot injection proved to be the best solutions. However, to limit greenhouse gas emissions and to meet strict on-road THC limits, efficient methane oxidation catalysts have to be found. 
Funding

The work presented is part of the Horzon2020 project "GasOn". This project has received funding from the European Union's Horizon 2020 research and innovation programme under grant agreement No 652816.
The Swiss partners have been supported by the Swiss State Secretariat for Education, Research and Innovation (SERI) under contract number 15.0145-1. The opinions expressed and arguments employed herein do not necessarily reflect the official views of the Swiss Government.

\section{Acronyms}

$\begin{array}{llll}\text { bmep } & \text { brake mean effective pressure } & \text { SCR } & \text { selective catalytic reduction } \\ \text { CA } & \text { crank angle } & \text { SOI } & \text { start of injection } \\ \text { CFD } & \text { computational fluid dynamics } & \text { TDC } & \text { top dead center } \\ \text { COC } & \text { center of combustion (i.e. crank angle, where } & \text { THC } & \text { total hydrocarbons } \\ & 50 \% \text { of the fuel is burned) } & \lambda & \text { stoichiometric air-fuel-ratio }\end{array}$

IMEP indicated mean effective pressure

\section{Bibliography}

[1] BACH, C., BÜTLER. T., HUBER, M. Abgasemissionen von Gasfahrzeugen. Aqua\&Gas. 2017, 7/8, 40-43.

[2] BACH, C., LÄMMLE, C., BILL, R. et al. Clean engine vehicle a natural gas driven Euro-4/SULEV with $30 \%$ reduced CO2-emissions. SAE Technical Paper 2004-01-0645. 2004. DOI:10.4271/2004-01-0645.

[3] BARDIS, K., XU, G., KYRTATOS, P. et al. A zero dimensional turbulence and heat transfer phenomenological model for pre-chamber gas engines. SAE Technical Paper 2018-011453, 2018. DOI:10.4271/2018-01-1453.

[4] BOLlA, M., SHAPIRO, E., KOTZAGIANNI, M. et al. Numerical study of fuel and turbulence distributions in an automotive-sized scavenged pre-chamber. Combustion Engines. 2019, 176(1), 63-68. DOI: 10.19206/CE-2019-108.

[5] CATON, J.A. A comparison of lean operation and exhaust gas recirculation: thermodynamic reasons for the increases of efficiency. SAE Technical Paper 2013-01-0266, 2013. DOI:10.4271/2013-01-0266.

[6] HÄNGGI, S., HILFIKER, T., SOLTIC, P. et al. Controloriented analysis of a lean-burn light-duty natural gas research engine with scavenged pre-chamber ignition. Combustion Engines. 2019, 176(1), 44-55. DOI: 10.19206/CE-2019-106.

[7] HUTTER, R., RITZMANN, J., ELBERT, P., ONDER, C. Low-load limit in a diesel-ignited gas engine. Energies. 2017, 10, 1-27. DOI:10.3390/en10101450.

[8] KAMMERMANN, T., KREUTNER, W., TROTTMANN, M et al. Spark-induced breakdown spectroscopy of methane/air and hydrogen-enriched methane/air mixtures at engine relevant conditions. Spectrochim Acta - Part B At Spectrosc. 2018, 148, 152-164. DOI:10.1016/j.sab.2018.06.013.

[9] KOTZAGIANNI, M., KYRTATOS, P., BOULOUCHOS, K. Optical investigation of prechamber combustion in an RCEM. Combustion Engines. 2018, 176(1), 12-17. DOI: 10.19206/ CE-2019-102.

Patrik Soltic, DEng. - ETH, Empa, Swiss Federal Laboratories for Materials Science and Technology, Dübendorf (Switzerland).

e-mail:Patrik.Soltic@empa.ch

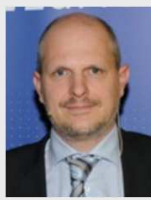

Richard Hutter, MEng. - ETH, Swiss Federal Institute of Technology, Zürich (Switzerland).

e-mail:RiHutter@idsc.mavt.ethz.ch
[10] KYRTATOS, P., BARDIS, K., BOLLA, M. et al. Transferability of insights from fundamental investigations into practical applications of prechamber combustion systems. Ignition Syst. Gasol. Engines - 4th Int. Conf. December 6-7, 2018, Berlin, IAV, 442-459.

[11] LUCAS, G., TALLU, G., WEIßNER, M. CFD-based development of an ignition chamber for a lean and high efficient CNG combustion. THIESEL 2018 Conf. Thermo- Fluid Dyn. Process. Direct Inject. Engines High-Pressure. 2018.

[12] N/N. International Energy Agency - World Energy Outlook. 2017.

[13] PIELECHA, I., BUESCHKE, W., SKOWRON, M. et al. Prechamber optimal selection for a two stage turbulent jet ignition type combustion system in CNG-fuelled engine. Combustion Engines. 2019, 176(1), 18-28. DOI: 10.19206/CE2019-103.

[14] SCHUlLER, O., REUTER, B., HENGSTLER, J. et al. Greenhouse gas intensity of natural gas transport. 2017.

[15] SHAPIRO, E., AHMED, I., TINEY, N. Advanced ignition modelling for pre-chamber combustion in lean burn gas engines. Ignition Syst. Gasol. Engines - 4th Int. Conf. December 6-7, 2018, Berlin, IAV, 104-121.

[16] THURNHEER, T, SOLTIC, P, DIMOPOULOS EGGENSCHWILER, P. S.I. engine fuelled with gasoline, methane and methane/hydrogen blends: Heat release and loss analysis. Int J Hydrogen Energy. 2009, 34, 2494-2503. DOI:10.1016/j.ijhydene.2008.12.048.

[17] Volkswagen. Volkswagen Konzern treibt gemeinschaftlichen Ausbau der Erdgas- Mobilität voran. Press Release from 020520172017.

[18] ZURBRIGGEN, F., HUTTER, R., ONDER, C. Dieselminimal combustion control of a natural gas-diesel engine. Energies. 2016, 9. DOI:10.3390/en9010058.

Thomas Hilfiker, Eng. - Empa, Swiss Federal Laboratories for Materials Science and Technology, Dübendorf (Switzerland).

e-mail:Thomas.Hilfiker@empa.ch

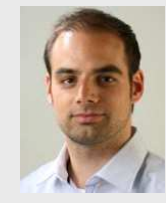

Severin Hänggi, MEng. - Swiss Federal Institute of

Technology, Zürich (Switzerland).

e-mail: SHaenggi@idsc.mavt.ethz.ch 